\title{
ARŞIVLENEN BELLEK OLARAK POSTA PULLARI VE SOSYO-KÜLTÜREL IŞLEVLERİ: KUZEY KIBRIS ÖRNEĞİ
POSTAGE STAMPS AS AN ARCIVED MEMORY AND ITS SOCIO-CULTURAL FUNCTION: NORTH CYPRUS EXAMPLE

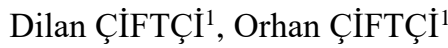

1. Yrd. Doç. Dr., Yakındoğu Üniversitesi, İletişim Fakültesi, dilan.ciftci@neu.edu.tr, https://orcid.org/0000-0003-3806-3915

2. Prof. Dr., Kıbrıs İlim Üniversitesi, Rehberlik Ve Psikolojik Danışmanlık Anabilim Dalı, orhanciftci@csu.edu.tr,

\begin{tabular}{|c|c|}
\hline Makale Türü & Article Type \\
\hline Araştırma Makalesi & Research Article \\
\hline Başvuru Tarihi & Application Date \\
\hline 19.02 .2020 & 02.19 .2020 \\
\hline Yayına Kabul Tarihi & Admission Date \\
\hline 25.07.2020 & 25.07.2020 \\
\hline & \\
\hline https://doi.org/10 & akuiibf.691464 \\
\hline
\end{tabular}

https://doi.org/10.30798/makuiibf.691464
Öz

19. yüzyılın ilk yarısında posta pullarının kullanımı, posta ücretinin ödendiğini gösteren belge olarak kabul edilmiş olsa da zamanla posta pulları tarihin simülasyonları olarak basit resimler ve çizimler içeren etiketler șeklinde yaygınlık kazanmıștır. Kıbrıs özelinde pullar ve onların temsiliyeti üzerine yapılan çalışmaların bulunmaması sebebiyle bu çalışmada 1970-1998 yılları arasında hazırlanan pulların incelenmesi Raento ve Brunn'un (2005) Sixteen Thematic Categories of Stamps kodlama cetveli kullanılarak yapılmıştır. Bu amaçla, çalışma kapsamında amaçlı örneklem metodu ile belirlenen 418 pul incelenmiștir. Elde edilen bulgular cerçevesinde, 1970-1998 yıllarında Kıbrıs toplumu ve cumhuriyetin tanıtımı amaciyla doğa ve sanat temalı posta pullarının basımının öne çıktığı görülmüştür. Bunun yanında söz konusu tarih aralığında posta pullarında KKTC ve TC arasındaki resmi ziyaretlerin anısına basilan pullar da dikkat çekmektedir. Bu bağlamda dünya futbol organizasyonları ve olimpiyatları için hazırlanan posta pullarının oldukça yaygın kullanıldığı görülmüștür. Aynı zamanda posta pullarının ülkelerin doğasını ve sağlık gibi temalarını tanıtım amaciyla basıldıklarını da söylenebilir. Bütün bunlara ilaveten tarihi mekanların, çiçek türlerinin ve hayvanların, resmi kuruluşların anısına da posta pullarının yayınlandığını görülmektedir. Bu çalışmada posta pullarında ideoloji ve propaganda yerine Kıbrıs Türk toplumunun oluşumu ve dünyaya entegre olması üzerinde yoğunlaşıldığı görülmüştür.

Anahtar Kelimeler: Tarih Anlatısı, Simülasyon, Posta Pulları, Kültürel Bellek, Arşivlenen Bellek,

\section{Abstract}

Although the use of postage stamps in the first half of the 19th century was accepted as a document indicating that the postage was paid, postage stamps became widespread in the form of simulations of history, including simple paintings and drawings. The lack of studies on the postage stamps and their representation in Cyprus, this study prepared between 1970-1998 postage stamps were analyzed by using the code of the Sixteen Thematic Categories of Stamps of Raento and Brunn (2005). For this purpose, 418 postage stamps determined by the purposive sampling method. It was revealed that stamps of nature-themed and art-themed postage stamps were used extensively between 1970 and 1998 for the purpose of introducing and promoting the Cypriot society and the republic. With the presentations on postage stamps, it is important to emphasize the state visits between the TRNC and the TC and to be integrated with the world. In this study, the formation of Turkish Cypriot community come to the fore in the rate of political messages and ideologies containing propaganda in postage stamps.

Keywords: History Narrative, Simulation, Postage Stamps, Cultural Memory, Archived Memory, 


\section{EXTENDED SUMMARY}

\section{Research Problem}

In this study, which was examined in terms of cultural memory and presentation codes on postage stamps, it clearly revealed socio-cultural changes in Northern Cyprus between 1970 and 1998 and the issues and situations that Turkish Cypriots put forward in order to adapt to the world. In this context, contrary to the stamps that are expected to emerge as political representations, it will not be wrong to say that the intensity of stamps on themes such as nature and health in the period in question was intended to promote rather than political propaganda. In the postage stamps examined within the scope of the study, historical stamps, flowers, animals and stamps made in memory of the establishment of official institutions and organizations attract attention. In this respect, it would be appropriate to say that the stamps between 1970-1998 are important reference sources for the establishment and subsequent promotion of the Turkish Republic of Northern Cyprus.

\section{Research Questions}

In presentation codes postage stamp relations with the Republic of Turkey metaphorically prepared with stamps for official visit to the state in 1974 to depict sports in terms of the desire to integrate with the world theme under the World Cup and the scales prepared for the Olympics stands out. In addition, the United Nations and the British Royal family stamps on the island's influence and continuity of external actors on the island is presented. In addition to this, the founding of the Turkish Republic of Northern Cyprus and the people selected for representation in the stamps containing important people are the prominent people for the Turkish Cypriot people. The aim of this study is to question and determine the possible postage stamps of Cyprus based on the memory of history. The production of the point stamps emphasized here is not only appealing to the period in which they were produced, but also to the past. What is important here is about the dominance and style of expression of deep histories.

\section{Literature Review}

Stamps do not consist of small pieces of paper affixed to envelopes and packages. On the contrary, as Pierce (1996: 62) states that "stamps represent sovereignty pul, stamps differ only from the state currencies used by the state themselves. Since stamps have this 'internal-external' role, they can be regarded as windows of the state. According to Brunn (2000), it is often possible to read the history of states with long stamps. If this history involves major conflicts or the transition from colonial status to political independence, stamps can show copyright, colonial events, military conflicts, monuments, personalities and events contributing to independence, and recent cultural achievements. Since the first stamps are important elements in state iconography, great care is taken to plan designs, colors, images, symbols and messages. Since symbolism and imagination are very important in state iconography, the authorities responsible for the promotion of cultural history can plan their first flag, a famous monument, a national coat of arms, and first stamps to show an important event in its history. The stamps are also 
related to international events such as Olympic games, major regional or global conferences, and important events in world history. States can be announced through the stamps of Olympic medals and international award winners (scientists, writers and diplomats). Some countries issue stamps to commemorate the events of other countries, such as America's biennial, the birth of Shakespeare and commemoration of world treaties. European countries issue EUROPA stamps each year with a common theme.

\section{Methodology}

In this study, stamps were discussed as the simulation of history through the memorial practices that he mostly applied while explaining the restructuring and shaping of social memory. However, in terms of historical time, representation and social memory, stamps are important in terms of both pointing to the historical process and representing the historical process it points to in terms of their rhetoric. In this context, a total of 418 stamps were examined in this study together with the 1970-1998 (28 year) stamp archive. The coding table created for the examination of the stamps in terms of the said historical time and representation of the stamps was prepared by adapting to the study based on the conceptualization of Raento and Brunn (2005) Sixteen Thematic Categories of Stamps. Permission was obtained from the authors to translate the mentioned categories and scale into Turkish. The declaration of permission is given in the attachment.

\section{Results and Conclusions}

In this study, which was examined in terms of cultural memory and presentation codes on postage stamps, it clearly revealed socio-cultural changes in Northern Cyprus between 1970 and 1998 and the issues and situations that Turkish Cypriots put forward in order to adapt to the world. In this context, contrary to the stamps that are expected to emerge as political representations, it will not be wrong to say that the intensity of stamps on themes such as nature and health in the period in question was intended to promote rather than political propaganda. In the postage stamps examined within the scope of the study, historical stamps, flowers, animals and stamps made in memory of the establishment of official institutions and organizations attract attention. In this respect, it would be appropriate to say that the stamps between 1970-1998 are important reference sources for the establishment and subsequent promotion of the Turkish Republic of Northern Cyprus. 


\section{GíRiș}

Bu çalışmanın amacı, Kıbrıs'ın kuzeyinde yayınlanan posta pullarının, tarihin belleğe katılımını sorgulamak ve anlamaktır. Bu çalışmada üzerinde durulan nokta pulların yalnızca üretildikleri döneme hitap eden değil, aynı zamanda geçmişi bugüne taşımasıdır. Burada önemli olan derin tarihlerin baskınlığı ve anlatım biçimi seçimidir. Bu çalışmada, tarihin anlatıları, bellek ve kolektif hatırlama, bilginin ve maddi kültür öğesi olarak pulların hatırlatma gücüne ilişkin olarak anma törenleri ve anmalarla ilgili pullar bağlamında tartışılacaktır.

Geleneksel medya aracı olarak kabul edilen kitle iletişim araçlarının yoğun etkinliği gerçekliğinden yola çıarak 19. Yüzyıl iletişim sürecine dönüldüğünde pullar posta ücretinin ödendiğini göstermek amacıyla üretilmiş ve kullanılmıştır. Genellikle küçük resimlerden oluşan bu pulların devletlerarası diplomaside çoğunlukla propaganda malzemesi olarak da kullanılmıştır. Bu bağlamda, farklı dönemlerde ve farklı ülkeler bağlamında posta pullarının sanatsal değeri ve ideolojik önemi üzerinde duran önemli çalışmalar bulunmasına rağmen (Reid, 1984; Davis,1985; Lauritzen, 1988; Nuessel ve Cicagno, 1992; Lutz ve Collins, 1993; Rose, 1996, 2001; Brunn, 2000; Banks, 2001; Goin, 2001; van Leeumanen ve Jewitt, 2001; Sturken ve Cartwright, 2001; Child, 2005; Dobson, 2002; Deans ve Dobson, 2005; Raento ve Brunn, 2005; Raento, 2006; Raento, 2016; Brunn, 2017; Klamar, Slivkova ve Brunn, 2018) Kıbrıs genelinde ve Kuzey Kıbrıs özelinde üretilen ve dolaşıma giren posta pullarının toplumsal bellek ve kültürel bellek ekseninde incelenmesi ile ilgili çalışmaların olmadığ 1 ortaya çıkmıştır.

\section{KAVRAMSAL ÇERÇEVE}

\subsection{Pulları Görsel Temsil Olarak Okumak}

Pullar, zarflara ve paketlere yapıştırılmış küçük kağıt parçalarından ibaret değildir. Aksine, Pierce'in (1996: 62) "pulların egemenliği ifade etmesini” belirtiği üzere gibi pullar, yalnızca devletin kendileri tarafından kullanılan devlet para birimlerinden farklıdır. Pulların bu 'iç-dış' rolü olduğu için devletin pencereleri olarak kabul edilmektedir.

Brunn (2000)'e göre uzun geçmişi olan devletler tarihlerini pullarıyla okumak çoğu zaman mümkündür. Bu tarih büyük çatışmalar veya sömürge statüsünden politik bağımsızlığa geçişi içeriyorsa, pullar telif hakkını, sömürgeci olayları, askeri çatışmaları, anıtları, bağımsızlığa katkıda bulunan kişilikleri ve olayları ve son kültürel başarıları gösterebilir. İlk pullar devlet ikonografisinde önemli unsurlar olduğu için tasarımları, renkleri, görüntüleri, sembolleri ve mesajları planlamaya büyük özen gösterilmektedir. Devlet ikonografisinde sembolizm ve imgelem çok önemli olduğu için kültürel tarihin tanıtımından sorumlu yetkililer, yeni bayraklarını, ünlü bir anıtı, ulusal armayı, tarihinin önemli bir etkinliğini göstermek için ilk pullarını planlayabilirler.

Pullar ayrıca olimpiyat oyunları, büyük bölgesel veya küresel konferanslar ve dünya tarihindeki önemli olaylar gibi uluslararası etkinliklerle de ilgilidir. Devletler Olimpiyat madalyalarının 
kazanılmasını ve uluslararası ödül kazananlar (bilim adamları, yazarlar ve diplomatlar) pullar aracılığıyla ilan edilebilir. Bazı ülkeler, diğer ülkelerin olaylarını anmak için pullar yayınlar: Amerika'nın iki yılda bir, Shakespeare'in doğumu ve dünya anlaşmalarını anma pulları yayınlaması gibi. Avrupa ülkeleri her yıl ortak bir temayla EUROPA pulları çıkarmaktadır.

\subsection{Bellek Mekân Olarak Pullar}

Toplumsal belleğin kökeni ile ilgili güçlü bir açıklama, Maurice Halbwachs'ın klasik eseri ‘On Collective Memory' (1992) adlı eserinde önerilmiştir. Halbwachs (1992), hatıraların doğası ve oluşumu üzerine yaptığı ilk çalışmalarında yazılı metinlerin bir araya gelerek toplumların koleksiyonunda birleşmesini toplumsal bellek olarak açıklar. Maurice Halbwachs (1992) toplumsal bellek üzerine yaptığı çalışmasında, aileler, toplumsal sınıflar ve dinler arasındaki bireysel anılar ve toplumsal olan arasındaki çelişkileri vurgular. Bu çalışmada çerçeveler içindeki bellek, posta pulları aracılığıyla aracılı gerçeklik olarak kabul edilmektedir. Bu nedenle, posta pulları, yeniden yapılanma sürecinde, aracılı yeniden yapılanmada kilit rol oynamaktadır (Halbwachs, 1992: 43).

\section{YÖNTEM}

$\mathrm{Bu}$ çalışmada pullar toplumsal belleğin yeniden yapılandırma ve şekillendirmeyi açılarken çoğunlukla başvurduğu anma pratikleri üzerinden ve görsel temsil biçimleri olarak tarihin simülasyonu olarak ele alınmıştır. Bununla birlikte, tarihsel zaman, temsil ve toplumsal bellek açısından pullar hem tarihsel sürece işaret etmesi hem de işaret ettiği tarihsel süreci kendi retorikleri açısından temsil etmesi anlamında önemlidir. Bu bağlamda bu çalışmada 1970-1998 (28 yıllık) pul arşiviyle birlikte toplam 418 pul incelenmiştir. Pulların söz konusu tarihsel zaman ve temsiliyeti anlamında pulların incelenmesi için oluşturulan kodlama cetveli ile çalışmada nitel yöntem ile içerik analizi yapılmış, analiz sonuçlarının betimsel ortaya koyulması amacıyla kullanım sıklıklarına yönelik niceliksel açıklamalara da ayrıca yer verilmiştir. Bu yolla, çalışmada Raento ve Brunn'un (2005) Sixteen Thematic Categories of Stamps kavramsallaştırmasından yola çıkılarak çalışmaya uyarlanarak hazırlanmıştır. Söz konusu kategorilerin ve ölçeğin Türkçeye çevrilip kullanılması için yazarlardan izin alınmıştır. İzin beyanı ekte sunulmuştur. $\mathrm{Bu}$ bağlamda çalışmada kullanılacak olan pulların konulara göre değerlendirilmesini özetleyen kategoriler Tablo 1'de özetlenmektedir.

Tablo 1. Pulların Değerlendirilmesinde Kullanılan Temalar Cetveli

\begin{tabular}{|l|l|}
\hline \multicolumn{1}{|c|}{ Pulların Teması } & \multicolumn{1}{c|}{ İçeriği } \\
\hline 1.Turizm, Boş Zaman ve Rekreasyon & Bu kategorideki pullar turizm ve tanıtım amacıyla hazırlanmış. \\
\hline 2.Devlet & Bu kategorideki pullar KKTC'nin kuruluşu ve ilgilidir. \\
\hline 3.Doğa & $\begin{array}{l}\text { Bu kategorideki pullar Kıbrıs adasının doğal güzellikleri ve } \\
\text { tarımı ile ilgilidir. }\end{array}$ \\
\hline 4.Uluslararası Referanslar & $\begin{array}{l}\text { Bu kategorideki pullar dünya genelinde kutlanan önemli } \\
\text { olaylar ve kişilerin anısına hazırlanmıştır. }\end{array}$ \\
\hline 5.Sağlık, Refah ve İyi Olma & $\begin{array}{l}\text { Bu kategorideki pullar herhangi bir sağlık sorununa işaret } \\
\text { etmektedir. AIDS vb. gibi. }\end{array}$ \\
\hline 6.Ekonomi & $\begin{array}{l}\text { Bu kategorideki pullar Kuzey Kıbrıs'ın gelir kaynakları ile } \\
\text { ilgilidir. }\end{array}$ \\
\hline
\end{tabular}




\begin{tabular}{|l|l|}
\hline 7.Tanımlanabilir Bireyler & Bu kategorideki siyasi figürleri içermektedir. \\
\hline 8.Kadınlar, Çocuklar ve Engelliler & $\begin{array}{l}\text { Bu kategorideki pullar kadın hakları, çocuk hakları ve } \\
\text { dezavantajlı gruplarla ilgilidir. }\end{array}$ \\
\hline 9.Sanat ve Kültür & Bu kategorideki pullar sanat eserleri ile ilgilidir. \\
\hline 10.Ulaştırma ve Haberleşme & $\begin{array}{l}\text { Bu kategorideki pullar Posta Dairesi ve telekomünikasyon } \\
\text { biriminin kuruluşu ile ilgilidir. }\end{array}$ \\
\hline 11.Folklor, Ritüeller & $\begin{array}{l}\text { Bu kategorideki pullar Kibrıs kültürünü ve ritüellerini temsil } \\
\text { etmektedir. }\end{array}$ \\
\hline 12.Savaş Güvenlik ve Silah & $\begin{array}{l}\text { Bu kategorideki pullar savaş ve zaferlerin anısına } \\
\text { hazıllanmıştır. }\end{array}$ \\
\hline 13.Spor & $\begin{array}{l}\text { Bu kategorideki pullar olimpiyatlar ve dünya genelindeki spor } \\
\text { faliyetlerini içermektedir. }\end{array}$ \\
\hline 14.Eğitim, Bilim ve Araştırma & $\begin{array}{l}\text { Bu kategorideki pullar buluşlar ve bilim insanlarını } \\
\text { içermektedir. } \\
\text { Bu kategorideki pullar dini konuları içermektedir. }\end{array}$ \\
\hline 15.Din & \begin{tabular}{l} 
\\
\hline
\end{tabular}
\end{tabular}

Çalışmada kullanılan posta pulları Kuzey Kıbrıs Türk Cumhuriyeti Posta Bölümü (1999) tarafindan yayınlanan A Description of the Commemorative Issues of Postage Stamps 1970-1988 başlıklı kitaptan edinilmiştir. Tablo 1'de belirtilen temalar çalışmanın örneklemini oluştururken anahtar kelimeler olarak da kullanılmıştır. Bu bağlamda söz konusu kitaptan anahtar sözcükler ışığında yayınlanan pulların fotoğrafları çekilerek 15 farklı kategoride arşivlenmiştir. Bu bilgiler 1şığında çalışmanın evrenini kitaptaki paylaşılan tüm pullar oluştururken, amaçlı örneklem tekniği kullanılarak çalışmanın örneklemi $418(n=418)$ posta pulu olarak belirlenmiştir. Şekil 115 farklı kategorideki 418 pulun 15 farklı kategoriye göre dağılımını ve yüzdeliklerini özetlemektedir.

Şekil 1. 15 Farklı Kategoride Listelenen Pulların Dağılımı

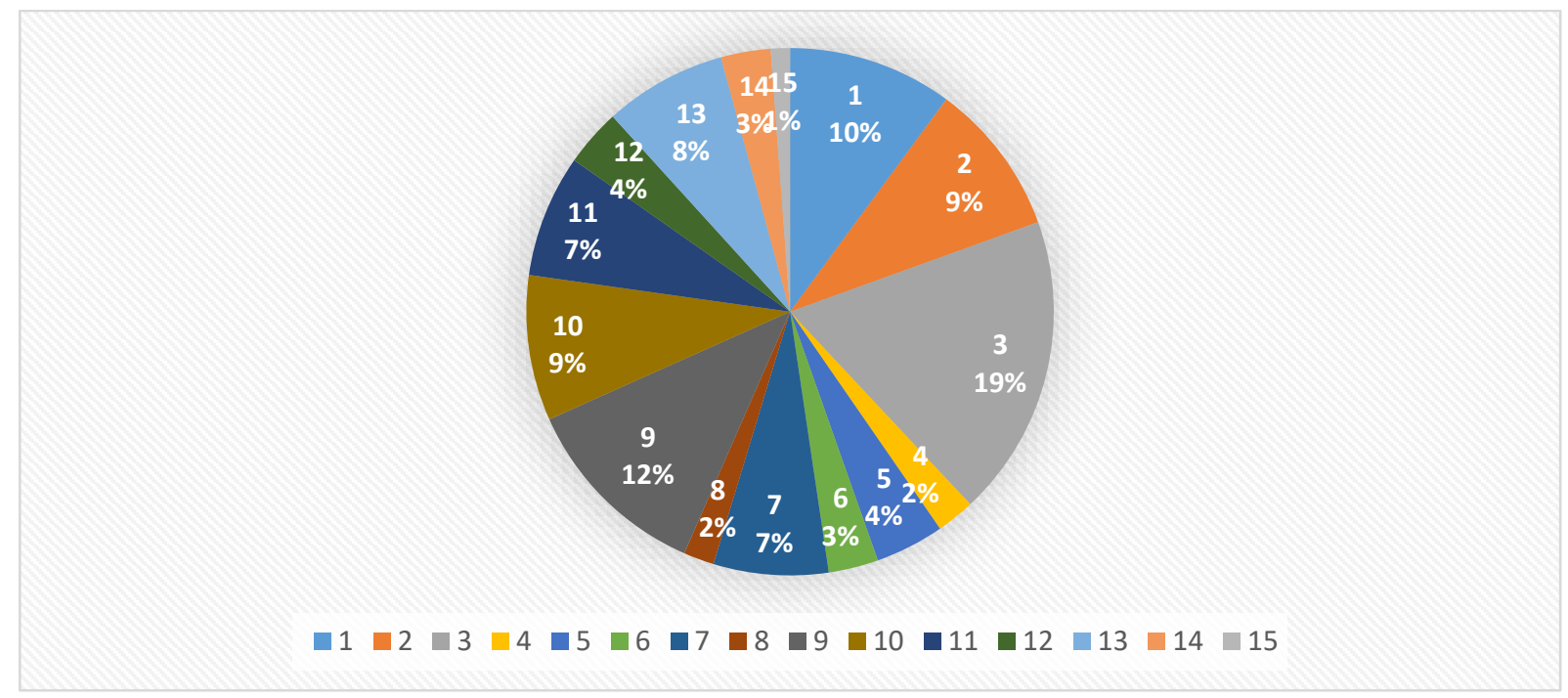

\section{BULGULAR}

Şekil 2'de en fazla pul basılan yıllar sırasıyla 1988 (n=27), $1990(n=26), 1992$ ( $n=24), 1991$ (n=23)'dir. 1988 yılının ön plana çıkmasının nedeni ise KKTC'nin kuruluşunun 5. Yılı olmasıdır. 1990 yılında devlet büyüklerinin ziyareti sıklıkla pullarda yer almaktadır. Kenan Evren ve Yıldırım Akbulut'un ziyaretleri gibi 1991 ve 1992 yıllarında Kuzey Kıbrıs’ta yetişen kır çiçekleri ve doğa 
güzelliği özellikle pulların temasını oluşturmaktadır. Şekil 2 pulların yıllara göre dağılımını özetlemektedir.

Şekil 2. Pulların Yıllara Göre Dağılımı

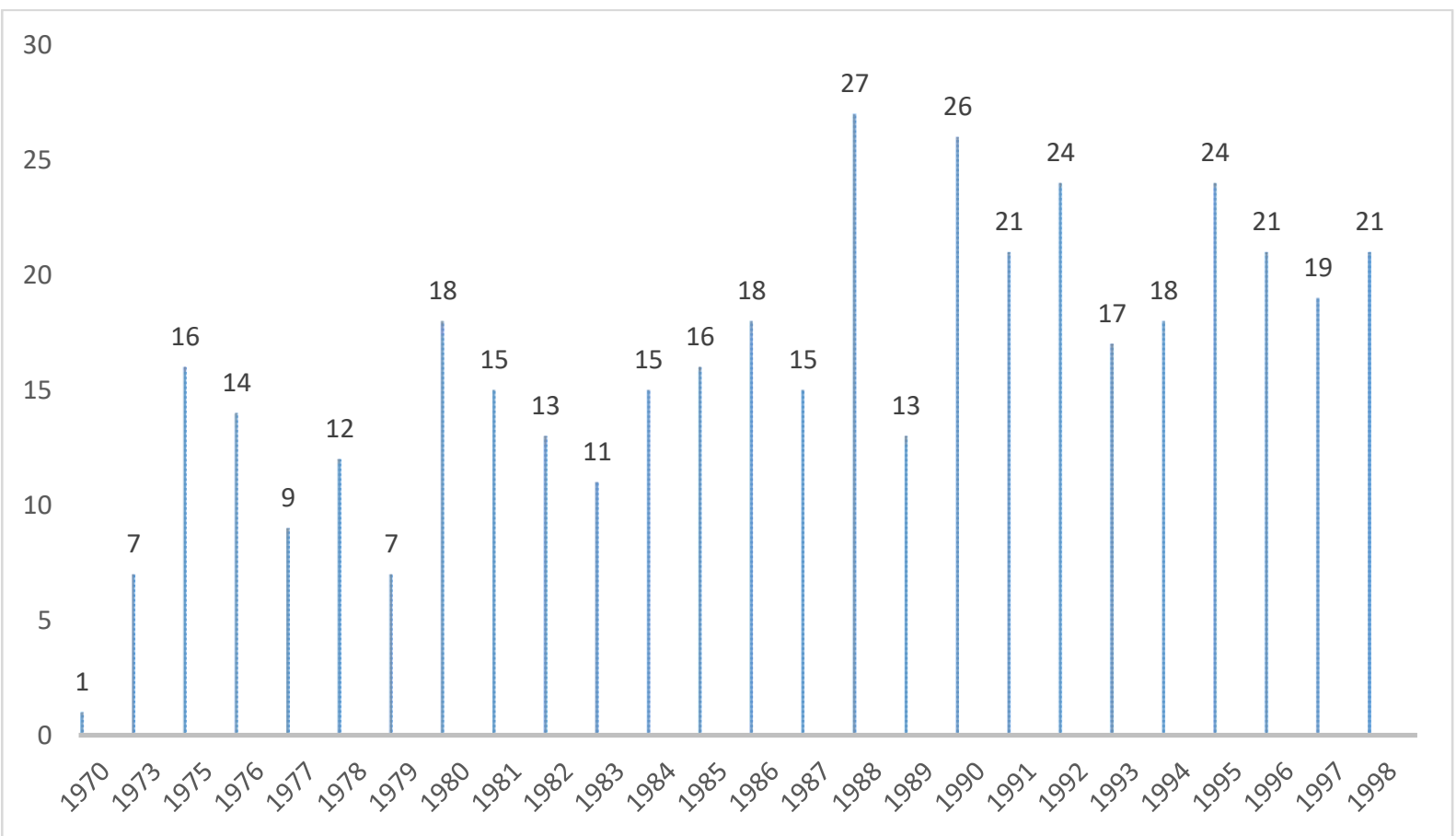

\subsection{Birinci Grup Pullar: Turizm, Boş Zaman ve Rekreasyon Temalı Pullar}

Turizm, boş zaman ve rekreasyon temasını içeren 1970-1998 yılları arasında 43 (n=43) tane pul bulunmaktadır. Bu pulların arasında turizm, boş zaman ve rekreasyon temasının öne çıktı̆̆ı yıl 1975 ( $\mathrm{n}=10)$ 'dir. Bununla birlikte sirasiyla, 1982, 1991, 1992 ve 1995 te turizm temalı konular pullarda işlenmiştir. Birinci grup temayı içeren pullar arsında öne çıkanların bazıları şu şekilde sıralanabilir: Atatürk Heykeli, Lal Mustafa Paşa Camii, St. Hilarion Kalesi, Namık Kemal Anıtı, Girne Limanı, Mağusa Plajı, Othello Kulesi, Girne Kalesi (1975 yılında çıkarılan pullar); Lambusa Krallığı ve Fosiller (1991 yılında çıkarılan pullar); Casino, Atış Poligamı, Buğday Camii, Salamis Bay Oteli (1992 yılında çıkarılan pullar); St. Barnabas Müzesi (1993 yılında çıkarılan pul) ve Girne Plajı, Salamis Harabeleri, Plaj Sörfü ve St. George Katedrali (1995 yılında çıkarılan pullar). Tablo 2 turizm, boş zaman ve rekreasyon kategorisindeki pulları özetlemektedir. Aynı zamanda Görsel 1 bu kategorideki bazı pulları göstermektedir.

Tablo 2. Turizm, Boş Vakit ve Rekreasyon Temasını İçeren Pullar

\begin{tabular}{|c|c|c|}
\hline Pulun Yılı & Pulun Teması & Sayısı (n=43) \\
\hline 1975 & Türk Federe Devleti Turistik Yerler & 10 \\
\hline 1976 & Turistik Seriler & 3 \\
\hline 1982 & Turizm & 4 \\
\hline 1986 & Sosyal Konutların Redifi & 3 \\
\hline 1988 & Turizm & 1 \\
\hline 1989 & Turizm (Venüs Kibrıs Adasının Sembolü) & 1 \\
\hline 1990 & Avrupa Turizm Yılı & 4 \\
\hline 1991 & Tarihi Yapılar & 3 \\
\hline
\end{tabular}




\begin{tabular}{|l|c|c|}
\hline 1991 & Turistik Manzaralar & 3 \\
\hline 1992 & Turistik Konular & 4 \\
\hline 1993 & Turistik Konular & 2 \\
\hline 1993 & Arabahmet Bölgesi Koruma Projesi & 2 \\
\hline 1995 & Turistik Konular & 4 \\
\hline 1996 & Bellapais Manastır1 & 1 \\
\hline
\end{tabular}

Görsel 1. Turizm, Boş Vakit Ve Rekreasyon Temalı Pulların Bazıları (Soldan Sağa Pulların Yayınlanma Yilları 1989, 1982, 1991)

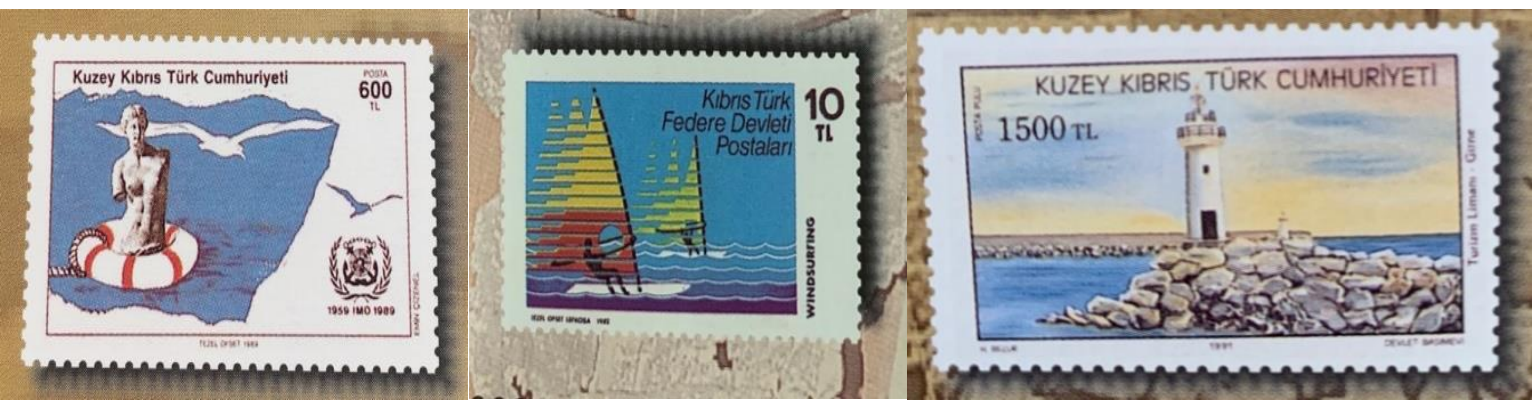

\section{2. İkinci Grup Pullar: Devlet Temalı Pullar}

Devlet temasını içeren 1970-1998 yılları arasında $40(\mathrm{n}=40)$ tane pul bulunmaktadır. Bu pullar genellikle Cumhuriyetin ilanı ve resmi devlet ziyaretlerini anmak üzere hazırlanan pullardan oluşmaktadır. Tablo 3 ikinci grup pulların isimlerini özetlemektedir. Bu gruptaki pullarda daha çok ulusal semboller, bayraklar ve devletin zümresini oluşturan kişilerin temsili öne çıkarken, Türkiye Cumhuriyeti'nin kuruluşu ile ilgili yıldönümü pullarına da yer verilmiştir. Aynı zamanda Görsel 2 bu kategorideki bazı pulları göstermektedir.

Tablo 3. Devlet Temasını İçeren Pullar

\begin{tabular}{|c|c|c|}
\hline Pulun Yılı & Pulun Teması & Sayısı $(n=40)$ \\
\hline 1973 & Türkiye Cumhuriyeti'nin 50. Y1ldönümü & 7 \\
\hline 1975 & Kıbris'ta Barıs & 3 \\
\hline 1976 & Özgürlük Anma Pulu & 2 \\
\hline 1980 & Kıbrıs Türk Federe Devleti & 1 \\
\hline 1980 & Kıbrıs Cumhuriyeti Yıldönümü & 3 \\
\hline 1984 & KKTC’nin İlanının 1. Yıldönümü & 2 \\
\hline 1987 & Turgut Özal'ın Resmi Ziyareti & 1 \\
\hline 1988 & Cenevre Barış Zirvesi & 1 \\
\hline 1988 & KKTC'nin Kuruluşunun 5. Yıldönümü & 1 \\
\hline 1988 & Turgut Özal'ın Resmi Ziyareti & 1 \\
\hline 1988 & Bülent Ecevit'in Resmi Ziyareti & 1 \\
\hline 1988 & Bülent Ulusu'nun Resmi Ziyareti & 1 \\
\hline 1988 & Resmi Ziyaret & 1 \\
\hline 1988 & KKTC'nin 5. Y1l1 & 1 \\
\hline 1989 & Erdal İnönü’nün Resmi Ziyaret & 1 \\
\hline 1990 & Kenan Evren'in Resmi Ziyaret & 1 \\
\hline 1990 & Yıldırım Akbulut'un Resmi Ziyaret & 1 \\
\hline 1993 & KKTC'nin 10. Y1l1 & 4 \\
\hline 1994 & TBMM'nin 75. Y1l1 & 1 \\
\hline 1995 & Süleyman Demirel'in Resmi Ziyaret & 1 \\
\hline 1997 & Necmettin Erbakan'ın Resmi Ziyaret & 1 \\
\hline 1997 & KKTC Bayrağ 1 & 1 \\
\hline 1998 & Barıș Suyu Projesi Süleyman Demirel'in Resmi Ziyareti & 1 \\
\hline
\end{tabular}




\begin{tabular}{|c|c|c|}
\hline 1998 & Bülent Ecevit'in Ziyareti & 1 \\
\hline 1998 & Mesut Y1lmaz'ın Resmi Ziyareti & 1 \\
\hline
\end{tabular}

Görsel 2. Devlet temalı pulların bazıları (Soldan sağa pulların yayınlanma yılları 1973, 1973, 1998, 1998)

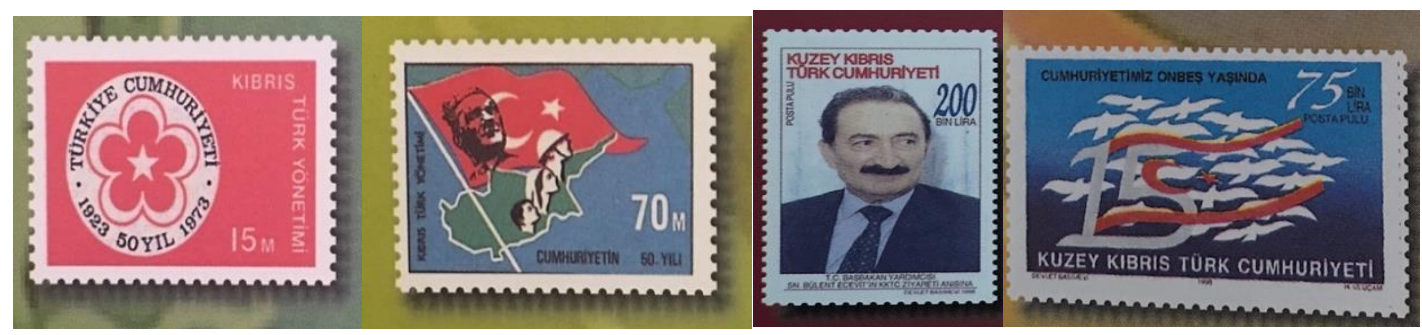

\section{3. Üçüncü Grup Pullar: Doğa Temalı Pullar}

Doğa temasını içeren 1970-1998 yılları arasında $79(\mathrm{n}=79)$ tane pul bulunmaktadır. Bu pullar genellikle yerel hayvan türlerinden, balıklardan, ağaçlardan, kelebeklerden, Kıbrıs'a özgü kır çiçeklerinden oluşmaktadır. Tablo 4 yıllara göre bu temada bulunan pulları özetlemektedir. Bu kategoride en fazla pul 1990 yılında nadir bitkiler (Onosma Caespttosum, Rosularia Cypria, Silene Fraudratrix, Arabis Cypria, Sedum Lampusae, Scutellaria Sibthorph) olarak hazırlanmıştır. Bununla birlikte Dünya Çevre Günü ile ilgili olarak da 1996 yılında ormanları resmeden 2 tane pul hazırlanmıştır. Ayrıca 16 farklı kategorinin içerisinde en fazla pul bulunan kategori olarak doğa temalı pullar 19701998 yılları arasındaki Kıbrıs pulları içerisinde önemli yer teşkil etmektedir. Aynı zamanda Görsel 3 bu kategorideki bazı pulları yıllara göre göstermektedir.

Tablo 4. Doğa Temasını İçeren Pullar

\begin{tabular}{|c|c|c|}
\hline Pulun Yılı & Pulun Teması & Sayısı (n=79) \\
\hline 1981 & Kır Çiçekleri & 4 \\
\hline 1982 & Kır Ççekleri & 4 \\
\hline 1983 & Kuşlar & 4 \\
\hline 1984 & Ormanlar & 1 \\
\hline 1985 & Yerel Hayvan Türleri & 4 \\
\hline 1989 & Kuşlar & 1 \\
\hline 1989 & Göl & 1 \\
\hline 1989 & Orman & 4 \\
\hline 1990 & Kuşlar & 6 \\
\hline 1990 & Nadir Bitkiler & 2 \\
\hline 1991 & Orkideler & 4 \\
\hline 1991 & Orkideler & 1 \\
\hline 1992 & Dünya Çevre Yılı & 1 \\
\hline 1992 & KKTC Veteriner Servisleri & 1 \\
\hline 1992 & Kedi & 4 \\
\hline 1993 & Anıt Ağaçlar & 3 \\
\hline 1994 & Deniz Kabukları & 3 \\
\hline 1995 & Avrupa Doğayı Koruma Yllı & 4 \\
\hline 1995 & Kelebekler & 2 \\
\hline 1996 & Dünya Çevre Günü & 1 \\
\hline 1996 & Temiz ve Sağlıklı Bir Çevrede Yaşamak Çocuklarımızın Hakkıdır & 4 \\
\hline 1996 & Balıklar & 1 \\
\hline 1996 & Nar Ağacı & 1 \\
\hline 1996 & Palmiye Ağacı & \\
\hline
\end{tabular}




\begin{tabular}{|c|c|c|}
\hline 1997 & Mantarlar & 4 \\
\hline 1997 & Kuşlar & 4 \\
\hline 1998 & Yararlı Böcekler & 4 \\
\hline 1998 & Uluslararası Okyanus Y11 & 2 \\
\hline
\end{tabular}

Görsel 3. Doğa Temalı Pulların Bazıları (Soldan Sağa Pulların Yayınlanma Yılları 1990, 1996, 1992, 1981,1983)
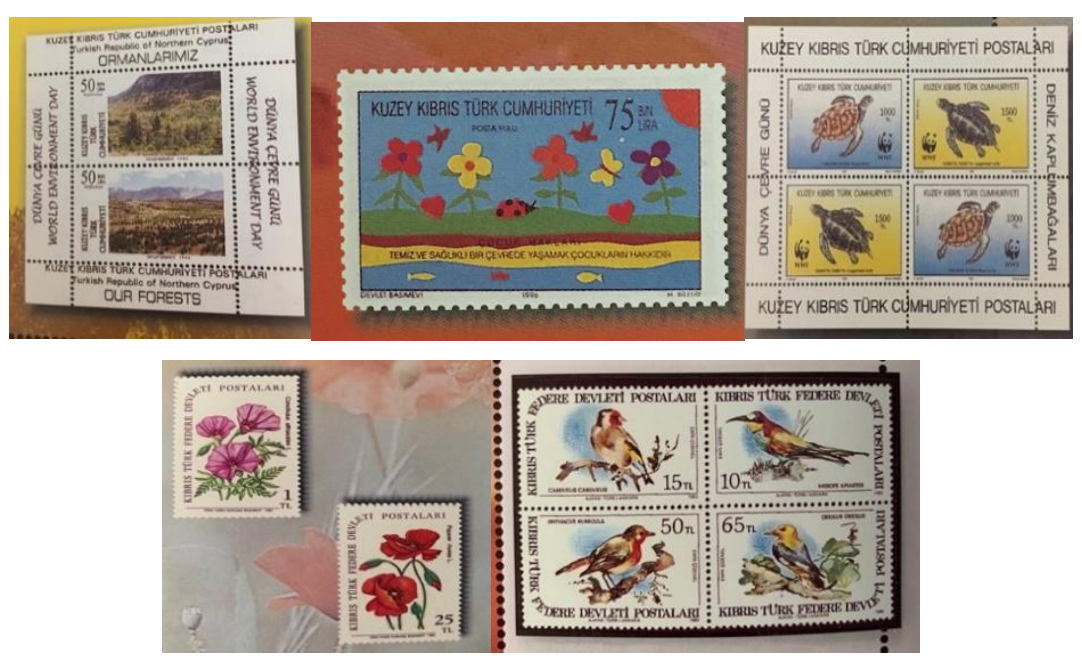

\subsection{Dördüncü Grup Pullar: Uluslararası Referans Temalı Pullar}

Uluslararası referans temasını içeren 1970-1998 yılları arasında $10 \quad(n=10)$ tane pul bulunmaktadır. Bu pullarda öne çıkan konulardan bazıları şu şekilde sıralanabilir: Filistin Halkı ile Dayanışma pulları iki yıl süreyle (1980-1981) hazırlanmıştır. Ayrıca Kıbrıs için önemli bir uluslararası referans kabul edilen Birleşmiş Milletlerin kuruluşunun 50. Yıldönümü anısına 1995 yılında hazırlanan pul ile 1988 yılında da İnsan Hakları Evrensel Beyannamesi’nin 50. Yılı anısına hazırlanan pullar öne çıkmaktadır. Tablo 5 uluslararası referans temasını içeren pulları yıllara göre özetlemektedir. Aynı zamanda Görsel 4 bu kategorideki bazı pulları göstermektedir.

Tablo 5. Uluslararası Referans Temasını İçeren Pullar

\begin{tabular}{|c|c|c|}
\hline Pulun Yılı & Pulun Teması & Sayısı (n=10) \\
\hline 1980 & Filistin Halkı ile Dayanışma & 2 \\
\hline 1981 & Filistin Halkı ile Dayanışma & 1 \\
\hline 1985 & BM'nin Kuruluşunun 40. Yıldönümü & 1 \\
\hline 1985 & Kızılhaç'ın 125. Hizmet Yı1lı & 1 \\
\hline 1986 & FAO & 1 \\
\hline 1987 & Uluslararası Eczacılar Federasyonu Üyeliği & 1 \\
\hline 1988 & İnan Hakları Evrensel Beyannamesi 50. Yıl1 & 1 \\
\hline 1995 & BM'nin Kuruluşunun 50. Yı1löönümü & 1 \\
\hline 1996 & Bosna-Hersek Konulu Pul & \\
\hline
\end{tabular}


Görsel 4. Uluslararası Referans Temalı Bazı Pullar (Soldan Sağa Pulların Yayınlanma Yılları 1986,

1987, 1998)

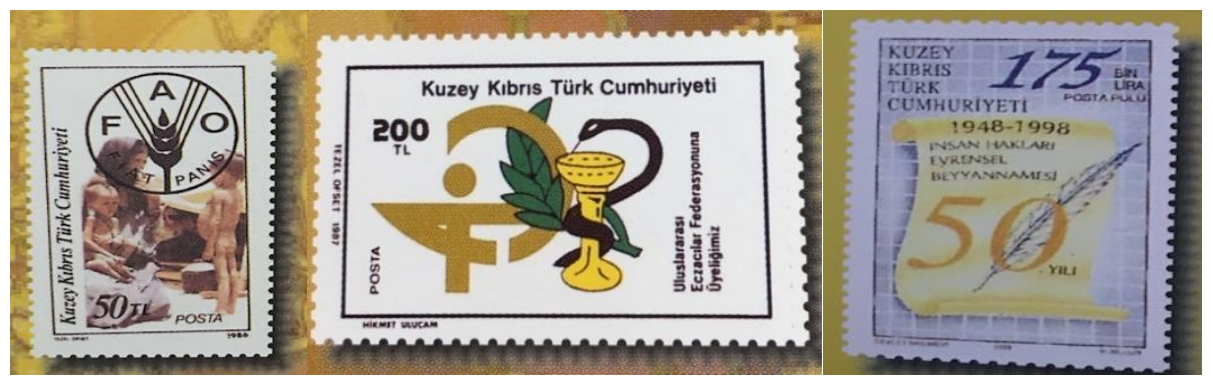

\subsection{Beşinci Grup Pullar: Sağlık, Refah ve İyi olma Temalı Pullar}

Sağlık, refah ve iyi olma temasını içeren 1970-1998 yılları arasında 18 ( $\mathrm{n}=18)$ tane pul bulunmaktadır. 1978 yılında sosyal sigortalar, yaşlılar ve engellilerle ilgili ilk defa pul çıkarıldığı için önemlidir. Ayrıca 1990 yılında Dünya Sağlık Günü ile ilgili 4 adet pul bulunmaktadır. Akdeniz ülkeleri için özel bir önem teşkil eden Talasamiya hastalığı farkındalığı için 'Talasamiya için Kan Tetkiki Yaptırılmalıdır' mesajını içeren pul 1985 yılında hazırlanmıştır. Benzer şekilde AIDS farkındalığı için de 1997 yılında bir pul bulunmaktadır. Ayrıca sağlık konusundaki gelişmelerin anısına çıkan pullar sırasıyla Verem ve Kuduz Aşılarının bulunuşunun 100. Y1lı anısına pullar bulunmaktadır. Tablo 6 sağlık, refah ve iyi olma temasını içeren pulları yıllara göre özetlemektedir. Aynı zamanda Görsel 5 bu kategorideki bazı pulları göstermektedir.

Tablo 6. Sağlık, Refah ve İyi Olma Temasını İçeren Pullar

\begin{tabular}{|c|c|c|}
\hline Pulun Yılı & Pulun Teması & Sayısı (n=18) \\
\hline 1970 & Türk Cemaat Meclisi Sosyal Yardım Pulu & 3 \\
\hline 1978 & Sosyal Sigortalar Pulu & 1 \\
\hline 1980 & Sosyal Yardım Pulu & 1 \\
\hline 1982 & Verem Basilinin Bulunuşunun 100. Y1lı & 1 \\
\hline 1985 & Talassamiya & 1 \\
\hline 1985 & Kuduz Așısının Bulunuşunun 100. Y1lı & 1 \\
\hline 1988 & Sivil Savunma & 2 \\
\hline 1990 & Dünya Sağlık Günü & 2 \\
\hline 1990 & Sigara ve Alkol & 1 \\
\hline 1991 & Dünya AIDS Farkındalık Y1lı & 1 \\
\hline 1991 & Yunus Emre Sevgi Yılı & 1 \\
\hline 1992 & Sosyal Sigortalar & 1 \\
\hline 1996 & Sivil Savunması yurt Savunması Olmaz & 1 \\
\hline 1997 & AIDS’i Tanı Kendini Koru & \\
\hline
\end{tabular}

Görsel 5. Sağlık, Refah ve İyi Olma Temalı Pulların Bazıları (Soldan Sağa Pulların Yayınlanma Y1llar1 1982, 1985, 1990)

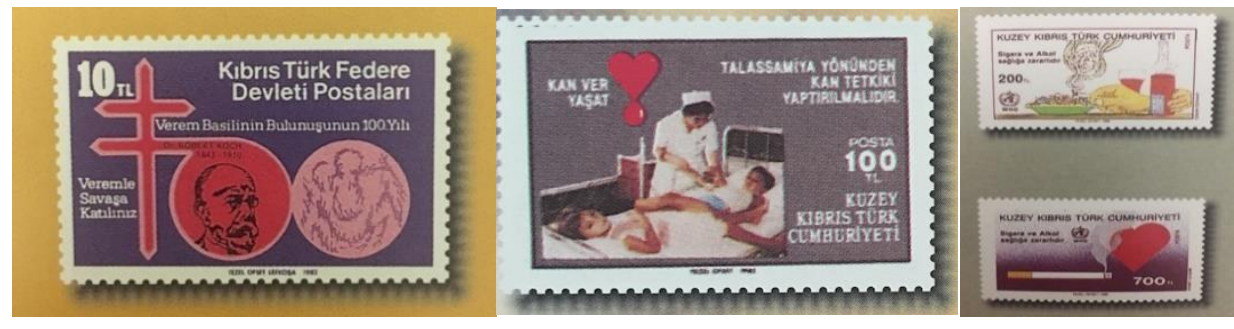




\subsection{Altıncı Grup Pullar: Ekonomi Temalı Pullar}

Ekonomi temasını içeren 1970-1998 yılları arasında $13(\mathrm{n}=13)$ tane pul bulunmaktadır. $\mathrm{Bu}$ pullar arasında özellikle 2 yıl öne çıkmaktadır. Bunlar 1976'da ihraç ürünleri olan portakal, mandalina, harnup, limon ve çilektir. Diğeri ise 1989 yılında tarımda kullanılan karasaban, döven ve yă̆ değirmenini içeren 3 tane puldur. Tablo 7 ekonomi temasını içeren pulların yıllara göre dağılımını özetlemektedir. Aynı zamanda Görsel 6 bu kategorideki bazı pulları göstermektedir.

Tablo 7. Ekonomi Temasını İçeren Pullar

\begin{tabular}{|c|c|c|}
\hline Pulun Yılı & Pulun Teması & Sayısı (n=13) \\
\hline 1976 & İhraç Ürünleri (portokal, mandalina, harnup vb.) & 5 \\
\hline 1987 & Yeni Girne Limanı & 1 \\
\hline 1989 & Free Port-Gazi Mağusa & 1 \\
\hline 1989 & Tarım & 1 \\
\hline 1989 & İçme Suyu & 1 \\
\hline 1989 & Tarım & 3 \\
\hline 1992 & Yeni Termik Elektrik Santrali-Girne & 1 \\
\hline
\end{tabular}

Görsel 6. Ekonomi Temalı Pulların Bazıları (Soldan Sağa Pulların Yayınlanma Yılları 1989, 1992, 1976)

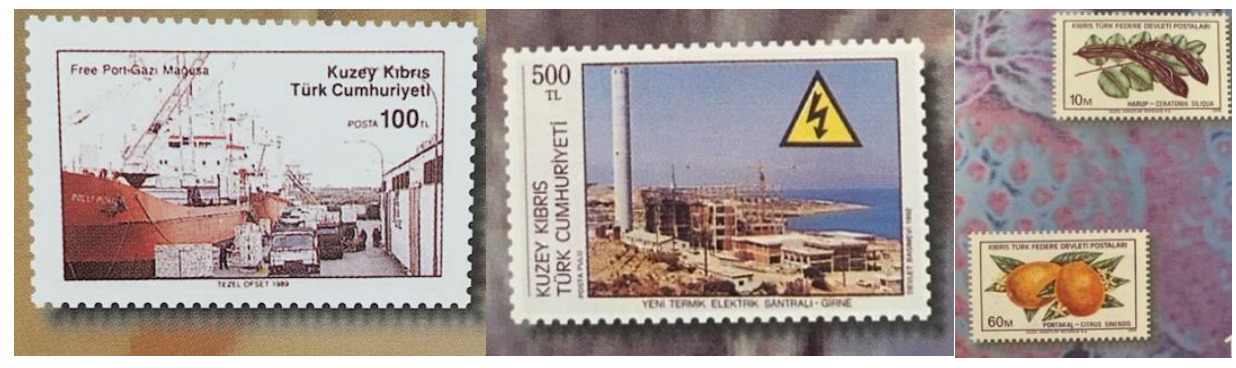

\subsection{Yedinci Grup Pullar: Önemli Kişiler Temalı Pullar}

Önemli kişiler temasını içeren 1970-1998 yılları arasında 30 (n=30) tane pul bulunmaktadır. $\mathrm{Bu}$ pullar arasında Atatürk'ü anma pulları öne çıkarken, diğer önemli politik figürler, araştırmacılar ve sanatçıların ölümlerinin anısına da pullar hazırlanmıştır. Tablo 8 önemli kişiler temalı pulların yıllara göre dağılımını özetlemektedir. Aynı zamanda Görsel 7 bu kategorideki bazı pulları göstermektedir.

Tablo 8. Önemli Kişiler Temasını İçeren Pullar

\begin{tabular}{|c|c|c|}
\hline Pulun Yılı & Pulun Teması & Sayısı (n=30) \\
\hline 1978 & Atatürk'ü Anma Pulu & 3 \\
\hline 1977 & Namık Kemal'i Anma & 2 \\
\hline 1981 & Atatürk'ün Doğumunun 100. Yıldönümü & 1 \\
\hline 1981 & Atatürk Tanıtma Serisi & 1 \\
\hline 1981 & Prens Charles ve Leydi Diana'nın Düğünü & 1 \\
\hline 1985 & İsmet İnönü & 2 \\
\hline 1985 & Dr. Fazıl Küçük 'ün Ölümünün 1. Yıldönümü & 2 \\
\hline 1986 & Kraliyet Ailesi Pulları & 3 \\
\hline 1987 & Osmanlı Paşaları & 4 \\
\hline 1988 & Atatürk’ün Ölümünün 50. Yıldönümü & 1 \\
\hline 1988 & Sedat Simavi & 2 \\
\hline 1990 & Van Gogh'un 100. Ölüm Yıldönümü & 1 \\
\hline 1991 & Başbakan Mustafa Çağatay & \\
\hline
\end{tabular}




\begin{tabular}{|c|c|c|}
\hline \hline 1993 & Atatürk & 1 \\
\hline 1994 & Dr. Fazıl Küçük’ün Ölüm Y1ldönümü & 1 \\
\hline 1995 & Pasteur'ün Ölümünün 100. Y1lı & 1 \\
\hline 1996 & Nasreddin Hoca Y1l1 & 1 \\
\hline 1998 & Ahmet Şevki Bey & 2 \\
\hline
\end{tabular}

Görsel 7. Önemli Kişiler Temasını İçeren Pulların Bazıları (Soldan Sağa Pulların Yayınlanma Yılları 1981, 1985, 1988, 1994)

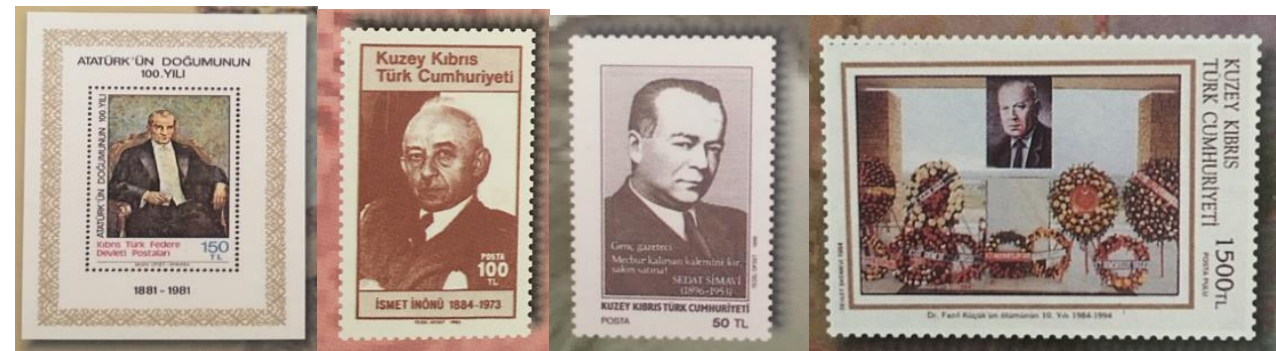

\subsection{Sekizinci Grup Pullar: Kadın, Çocuk ve Dezavantajlı Gruplar Temalı Pullar}

Kadın, çocuk ve dezavantajlı gruplar temasını içeren 1970-1998 yılları arasında 8 (n=8) tane pul bulunmaktadır. Sırasıyla bu pullar, 1979 yılı Dünya Çocuk Yılına özel 3 adet, 1981 yılında Uluslararası Engelliler Yılına özel 3 adet pul bulunmaktadır, bunların arasında 1rk ayrımını kınama pulu öne çıkarken, son olarak Uluslararası Gençlik Yılı anısına 2 adet pul basılmıştır. Tablo 9 kadın, çocuk ve dezavantajlı gruplar temasını içeren pulların yıllara göre dağılımını özetlemektedir. Aynı zamanda Görsel 8 bu kategorideki bazı pulları göstermektedir.

Tablo 9. Kadın, Çocuk ve Dezavantajlı Gruplar Temasını İçeren Pullar

\begin{tabular}{|c|c|c|}
\hline Pulun Yılı & Pulun Teması & Sayısı (n=8) \\
\hline 1979 & Dünya Çocuk Yıl1 & 3 \\
\hline 1981 & Uluslararası Engelliler Y11 & 3 \\
\hline 1985 & Uluslararası Gençlik Y1lı & 2 \\
\hline
\end{tabular}

Görsel 8. Kadın, Çocuk ve Dezavantajlı Gruplar Temasını İçeren Bazı Pullar (Soldan Sağa Pulların Yayınlanma Yilları 1979, 1979, 1985)

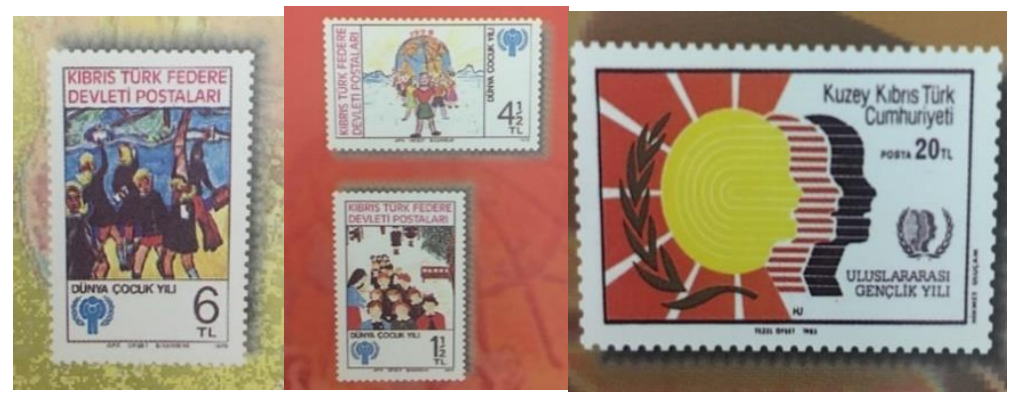

\subsection{Dokuzuncu Grup Pullar: Sanat ve Kültür Temalı Pullar}

Sanat ve kültür temasını içeren 1970-1998 yılları arasında $50(n=50)$ tane pul bulunmaktadır. Bunların arasından 1980 yılında Hz. Ömer Türbesi, Kalesi Mağusa, Bellapais ve Selimiye Camii gibi pullar bulunurken, 1977 yılında Kıbrıs Türk Eserleri adı altında Arabahmet Camii, Bekir Paşa Su Kanalları ve Baf Kalesi, 1986 yılında Bronz Çağ’a ait arkeolojik kalıntılar öne çıkmaktadır. Bunun yanında, Kıbrıs’ta Barışı Anma Sergisi ve Özgürlük Anma Sergisi pulları 1975 ve 1976 yıllarında 
önemli bir yer bulmaktadır. Diğer pullar ise genellikle 1988 ve 1989 yıllarında çeşitli tablo ve resimlerden oluşmaktadır. Son olarak, Devlet Tiyatrolarının Kuruluşu ve Sinemanın 100. Yılı anısına da pullar düzenlenmiştir. Tablo 10 sanat ve kültür temalı pulların yıllara göre dağılımını özetlemektedir. Aynı zamanda Görsel 9 bu kategorideki bazı pulları göstermektedir.

Tablo 10. Sanat ve Kültür Temasını İçeren Pullar

\begin{tabular}{|c|c|c|}
\hline Pulun Yılı & Pulun Teması & Sayısi (n=50) \\
\hline 1975 & Kibrıs'ta Barışı Anma Sergisi & 3 \\
\hline 1976 & Özgürlük Anma Sergisi & 2 \\
\hline 1977 & Kıbrıs'ta Türk Eserleri & 4 \\
\hline 1978 & Ulusal Anıt & 3 \\
\hline 1980 & Tarihi Eserler & 5 \\
\hline 1984 & Atatürk Kültür Merkezi & 1 \\
\hline 1984 & Resimler & 2 \\
\hline 1985 & Tablolar & 2 \\
\hline 1986 & Resimler & 2 \\
\hline 1986 & Karagöz-Hacivat & 1 \\
\hline 1986 & Tarihi Kalıntılar & 4 \\
\hline 1987 & Resimler & 2 \\
\hline 1988 & Resimler & 3 \\
\hline 1989 & Resimler & 3 \\
\hline 1989 & SADED & 1 \\
\hline 1991 & Mozart & 1 \\
\hline 1991 & Aşık Mene Resimleri & 2 \\
\hline 1992 & Resimler & 2 \\
\hline 1993 & KKTC Devlet Tiyatroları & 1 \\
\hline 1993 & Çaykovski'nin 100. Ölüm Yılı & 1 \\
\hline 1994 & Sanat Eserleri & 2 \\
\hline 1995 & Sinemanın 100. Yılı & 1 \\
\hline 1997 & Resimler & 2 \\
\hline
\end{tabular}

Görsel 9. Sanat ve Kültür Temasını İçeren Bazı Pullar (Soldan Sağa Pulların Yayınlanma Yılları 1975, 1989, 1991)

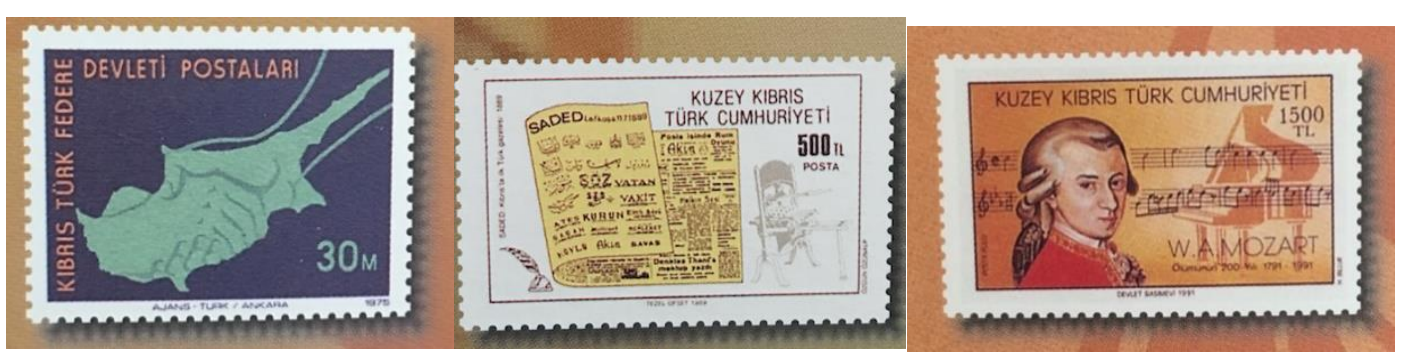

\subsection{Onuncu Grup Pullar: Ulaștırma ve Haberleșme Temalı Pullar}

Ulaştırma ve haberleşme temasını içeren 1970-1998 yılları arasında $38(\mathrm{n}=38)$ tane pul bulunmaktadır. Bu kategoride en fazla pul 1994 yılında düzenlenen Köy Pullarının Kullanışının 100. Yıldönümü pullarıdır. Bununla birlikte 1978 yılında kara, deniz ve hava ulaşımına ilişkin pullar da hazırlanmıştır. Ayrıca 1979 yılında Uluslararası Telekomünikasyon Birliği anısına 3 adet pul düzenlenmiştir. Trafik işaret ve kurallarını kapsayan 3 adet pul ise 1990 yılında Hayat Sigortası mesaj1 ile hazırlanmıştır. Buna ilaveten deniz fenerini konu alan 3 adet pul 1991 yılında KKTC Deniz Fenerleri olarak kayıtlara geçmiştir. 1983 yılında ise Dünya Haberleşme Yılı anısına 2 adet pul hazırlanırken, 
bugün yok olan Kıbrıs Tren Yolları ile ilgili 1986 yılında 2 adet pul düzenlenmiştir. Kıbrıs kurum ve kuruluşları anısına yapılan pullar ise kronolojik olarak sırasıyla şu şekildedir: Kuzey Kıbrıs Türk Hava Kurumu, Kıbrıs Türk Hava Yolları, BRT’nin 35. Yı1ı Anısı, Kıbrıs Türk Postalarının 25. Yı1ı Anıs1 puludur. Son olarak radyonun 100. Yılı anısına bir pul da bu kategoride 1995 yılında öne çıkmaktadır. Tablo 11 ulaştırma ve haberleşme temalı pulların yıllara göre dağılımını özetlemektedir. Aynı zamanda Görsel 10 bu kategorideki bazı pulları göstermektedir.

Tablo 11. Ulaştırma ve Haberleşme Temasını İçeren Pullar

\begin{tabular}{|c|c|c|}
\hline Pulun Yılı & Pulun Teması & Sayısı $(n=38)$ \\
\hline 1980 & Kıbrıs'ta Basılan İlk Pulların Anısına Basılan Pullar & 2 \\
\hline 1978 & Ulaşım & 3 \\
\hline 1979 & Dünya Telekomünikasyon Birliği Anı Pulları & 3 \\
\hline 1980 & Kıbrıs Türk Federe Devleti Postaları & 1 \\
\hline 1983 & Dünya Haberleşme Y1lı & 2 \\
\hline 1985 & Kuzey Kıbrıs Türk Hava Kurumu & 1 \\
\hline 1986 & Kibrıs Türk Hava Yolları & 2 \\
\hline 1986 & Tren Yollar1 & 2 \\
\hline 1988 & Bayrak Radyo Televizyon Kurumu'nun Kuruluşunun 35. Y1l1 & 1 \\
\hline 1989 & Kıbrıs Türk Postalarının 25. Yılı & 1 \\
\hline 1989 & Tren Yolu & 1 \\
\hline 1990 & Trafik & 3 \\
\hline 1991 & Deniz Fenerleri & 3 \\
\hline 1992 & Sivil Havacılık Hizmetleri & 1 \\
\hline 1992 & Meteoroloji & 1 \\
\hline 1992 & Haritacılık & 1 \\
\hline 1993 & Basın ve Yayın & 1 \\
\hline 1994 & Köy Pullarının Kullanılıșııın 100. Yıldönümü & 5 \\
\hline 1995 & Radyonun 100. Y1l1 & 1 \\
\hline 1995 & Devlet Basımevinin 20. Y1l1 & 1 \\
\hline 1995 & TC Cumhurbaşkanı Süleyman Demirel'in Orhun Anıtlarını Ziyareti & 2 \\
\hline
\end{tabular}

Görsel 10. Ulaştırma ve Haberleşme Temalı Pulların Bazıları (Soldan Sağa Pulların Yayınlanma Y1llar1 1980, 1979, 1983, 1985)

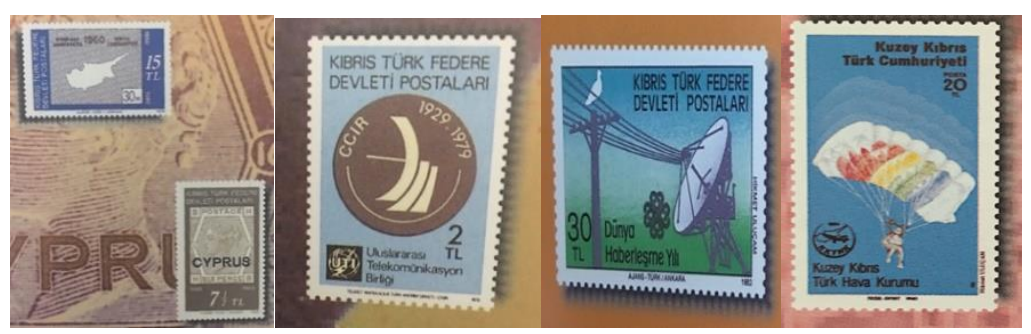

\subsection{On Birinci Grup Pullar: Folklor, Ritüeller ve Gelenekler Temalı Pullar}

Folklor, ritüeller ve gelenekler temasını içeren 1970-1998 yılları arasında $32(\mathrm{n}=32)$ tane pul bulunmaktadır. Bu kategorideki pullar geleneksel kıyafetler (1987), halk dansları (1996), geleneksel yemekler (1992 ve 1995) ve kullanılan paralar (1997) şeklinde sıralanabilir. Ayrıca, kaybolan el sanatları ile ilgili pullar ise 1998 yılında kalaycılık, oymacılık, sepetçilik ve bileyiciler olarak öne çıkmaktadır. Son olarak Kıbrıs el sanatlarının resmedildiği pullar 1977 yılında düzenlenmiştir. Tablo 12 
folklor, ritüeller ve gelenekler temasını içeren pulların yıllara göre dağılımını özetlemektedir. Aynı zamanda Görsel 11 bu kategorideki bazı pulları göstermektedir.

Tablo 12. Folklor, Ritüeller ve Gelenekler Temasını İçeren Pullar

\begin{tabular}{|c|c|c|}
\hline Pulun Yılı & Pulun Teması & Sayısı (n=32) \\
\hline 1977 & Kıbrıs El Sanatları & 3 \\
\hline 1982 & Kıbrıs Düğünü ve Harnup Toplayıcıları & 2 \\
\hline 1983 & Leymosun Otobüsü ve Nasırlı Eller & 2 \\
\hline 1987 & Folklor & 4 \\
\hline 1988 & Kardeşlik & 1 \\
\hline 1992 & Kibris Mutfăg 1 & 4 \\
\hline 1995 & Kibrıs Mutfağı & 3 \\
\hline 1996 & Folklor & 1 \\
\hline 1997 & Kullanılan Paralar & 4 \\
\hline 1998 & Eski Kapılar & 2 \\
\hline 1998 & Çocuk Halk Dansları Festivali Etkinliği & 2 \\
\hline 1998 & Kaybolan El Sanatları (Kalaycı, Oymacı, Sepetçi, Bileyici) & 4 \\
\hline
\end{tabular}

Görsel 11. Folklor, Ritüeller ve Gelenekler Temasını İçeren Bazı Pullar (Soldan Sağa Pulların Yayınlanma Yılları 1988, 1998, 1998)

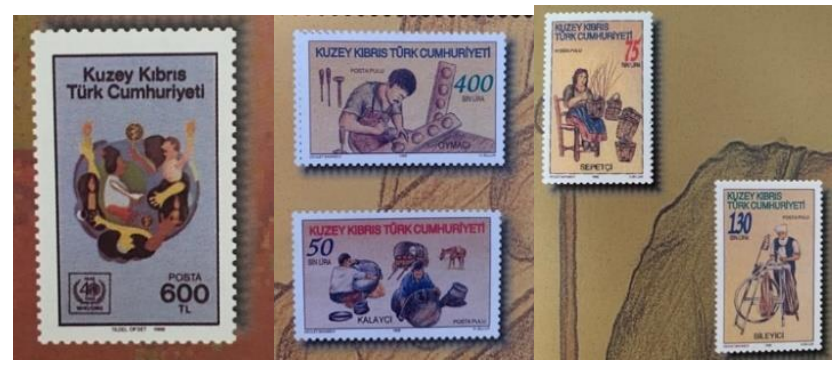

\subsection{On İkinci Grup Pullar: Savaş, Askerlik ve Güvenlik Temalı Pullar}

Savaş, askerlik ve güvenlik temasını içeren 1970-1998 yılları arasında $15(\mathrm{n}=15)$ tane pul bulunmaktadır. Bu kategorideki pullar arasında öne çıkan pullar Kıbrıs Barış Harekatı'nın 5. 10. Ve 20. Yılı anısına çıkan pullar, Güvenlik Kuvvetleri Komutanlığı'nın kuruluşunun 20. Y1lı ve Türk Mukavemet Teşkilatı'nın (TMT) 25. Yılı anısına çıkan pullardır. Tablo 13 savaş, askerlik ve güvenlik temalı pulların yıllara göre dağılımını özetlemektedir. Aynı zamanda Görsel 12 bu kategorideki bazı pulları göstermektedir.

Tablo 13. Savaş, Askerlik ve Güvenlik Temasını İçeren Pullar

\begin{tabular}{|c|c|c|}
\hline Pulun Yılı & Pulun Teması & Sayısı (n=15) \\
\hline 1979 & Kıbrıs Barış Harekatı'nın 5. Yı1lönümü & 1 \\
\hline 1983 & TMT'nin 25. Yılldönümü & 3 \\
\hline 1984 & Kıbrıs Barış Harekatı'nın 10. Yıldönümü & 2 \\
\hline 1986 & Güvenlik Kuvvetleri Komutanlı̆̆1 & 1 \\
\hline 1987 & Piyade Alayı'na Sancağın İlk Teslimi Töreni & 1 \\
\hline 1989 & Erenköy Direnişi'nin 25. Yılı & 1 \\
\hline 1993 & TMT & 1 \\
\hline 1994 & Kibrıs Barış Harekatı'nın 20. Yıldönümü & 4 \\
\hline 1996 & Güvenlik Kuvvetleri Komutanlı̆̆ı'nın Kuruluşu'nun 20. Yılı & 1 \\
\hline
\end{tabular}


Görsel 12. Savaş, Askerlik ve Güvenlik Temalı Pulların Bazıları (Soldan Sağa Pulların Yayınlanma Yillar1 1979, 1983, 1984,1986,1993)
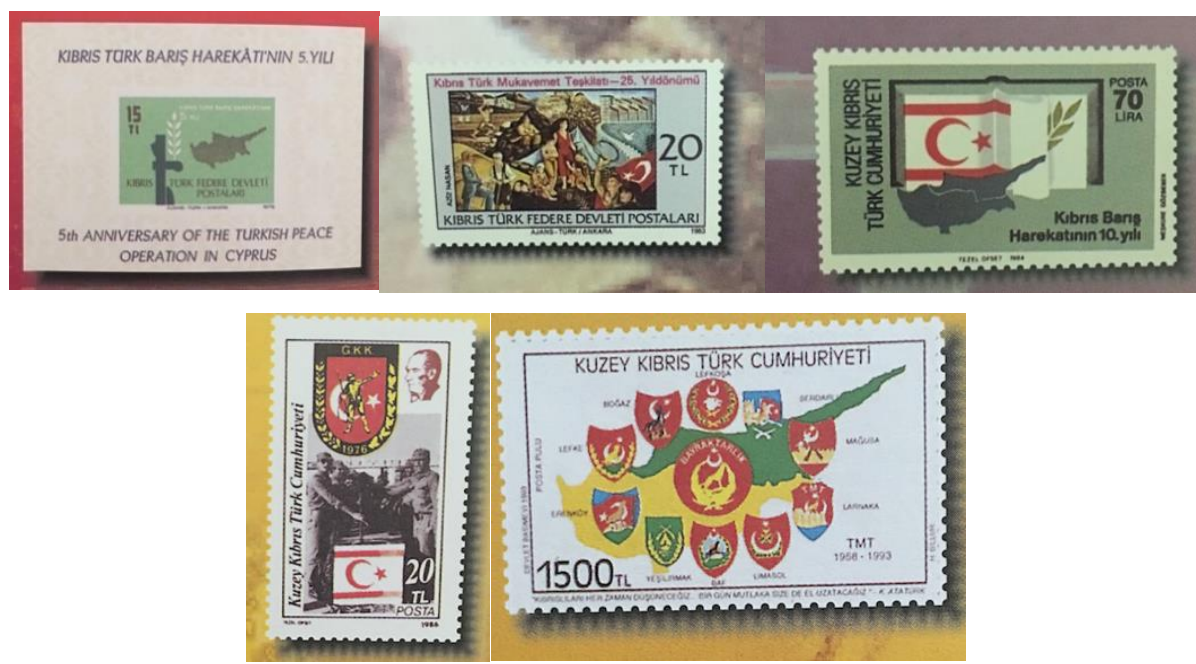

\subsection{On Üçüncü Grup Pullar: Spor Temalı Pullar}

Spor temasını içeren 1970-1998 yılları arasında $32(\mathrm{n}=32)$ tane pul bulunmaktadır. Genellikle Dünya Futbol Kupası ve Dünya Olimpiyatlarını içeren anı pulları bu kategoride öne çıkmaktadır. Tablo 14 spor temalı pulların yıllara göre dağılımını özetlemektedir. Aynı zamanda Görsel 13 bu kategorideki bazı pulları göstermektedir.

Tablo 14. Spor Temasını İçeren Pullar

\begin{tabular}{|c|c|c|}
\hline Pulun Yılı & Pulun Teması & Sayısı (n=32) \\
\hline 1976 & Kibrıs Türk Federe Devleti Monteal Olimpiyat Oyunları & 2 \\
\hline 1982 & Dünya Futbol Kupası & 1 \\
\hline 1982 & İzciliğin Kuruluşunun 75. Yıldönümü & 1 \\
\hline 1984 & Los Angeles Olimpiyatları & 2 \\
\hline 1984 & Uluslararası Tekvando Şampiyonası & 5 \\
\hline 1986 & Mexico 86 Olimpiyatları & 1 \\
\hline 1988 & Seul Olimpiyatları & 3 \\
\hline 1990 & İtalya Dünya Kupas1 & 2 \\
\hline 1992 & Barselona Olimpiyatları & 4 \\
\hline 1994 & Dünya Kupası & 2 \\
\hline 1996 & Atlanta Olimpiyat Oyunları & 4 \\
\hline 1996 & Dünya Futbol Şampiyonas1 & 2 \\
\hline 1997 & İzciliğin 90. Y1l1 & 1 \\
\hline 1998 & Fransa Dünya Kupas1 & 2 \\
\hline
\end{tabular}

Görsel 13. Spor Temalı Pulların Bazıları (Soldan Sağa Pulların Yayınlanma Yılları 1982, 1982, 1984,1986)

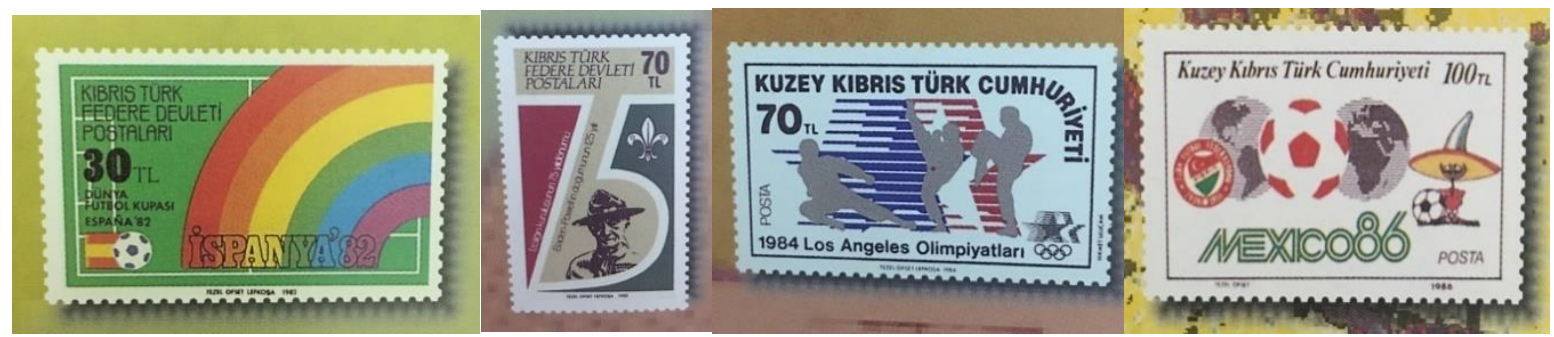




\subsection{On Dördüncü Grup Pullar: Eğitim, Bilim ve Araştırma Temalı Pullar}

Eğitim, bilim ve araştırma temasını içeren 1970-1998 yılları arasında 13 (n=13) tane pul bulunmaktadır. Bu pulların arasında öne çıkan konular şu şekildedir: 1990 Dünya Okuma ve Yazma Y1lı, 1995 Lefkoşa Türk Lisesi’nin 100. Yıl1, 1987 Doğu Akdeniz Üniversitesi’nin Kuruluşu, 1988 Uluslararası Girne Konferansıdır. Tablo 15 eğitim, bilim ve araştırma temalı pulların yıllara göre dağılımını özetlemektedir. Aynı zamanda Görsel 14 bu kategorideki bazı pulları göstermektedir.

Tablo 15. Eğitim, Bilim ve Araştırma Temasını İçeren Pullar

\begin{tabular}{|c|c|c|}
\hline Pulun Yılı & Pulun Teması & Sayısı (n=13) \\
\hline 1986 & Halley Yıldızı & 1 \\
\hline 1987 & Beşinci İslam Zirve Konferans1 & 1 \\
\hline 1987 & Doğu Akdeniz Üniversitesi’nin Kuruluşu & 1 \\
\hline 1988 & Uluslararası Kuzey Kıbrıs Fuarı & 1 \\
\hline 1988 & Uluslararası Girne Konferansı & 1 \\
\hline 1990 & Dünya Okuma ve Yazma Yılı-Baş Öğretmen Atatürk & 2 \\
\hline 1991 & Doğu Akdeniz Üniversitesi & 1 \\
\hline 1992 & KKTC'de Harita Çalışmaları & 1 \\
\hline 1992 & Meteoroloji Hizmetleri & 1 \\
\hline 1995 & Lefkoş Türk Lisesi 100. Yılı & 1 \\
\hline 1997 & Dizel Motorun İcadı & 1 \\
\hline 1997 & AIDS Ĕgitimi & 1 \\
\hline
\end{tabular}

Görsel 14. Eğitim, Bilim ve Araştırma Temalı Pulların Bazıları (Soldan Sağa Pulların Yayınlanma Yillar1 1987, 1988, 1991, 1995)

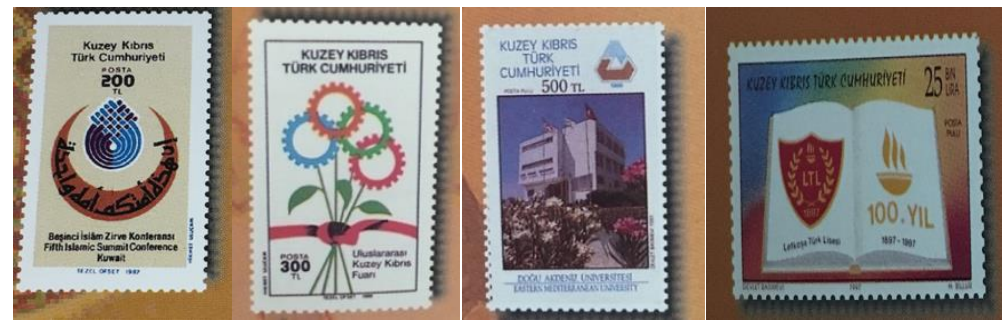

\subsection{On Beşinci Grup Pullar: Din Temalı Pullar}

Din temasını içeren 1970-1998 yılları arasında $5(\mathrm{n}=5)$ tane pul bulunmaktadır. Sirasıyla bu pullar, 1980 İslam Anma Serisi pulları olarak Hicretin 15. Yüzyılı anısı pulu, Dünya İslam Konferansı 8. Genel Kurulu, Kıbrıs Türk Federe Devleti ilk İslam Konferansı anı pulu ve 1981 yılında İslam Ülkeleri Dayanışma Günü anısına hazırlanan Türkçe ve İngilizce pullardır. Aynı zamanda Görsel 15 bu kategorideki bazı pulları göstermektedir.

Tablo 16. Din Temasını İçeren Pullar

\begin{tabular}{|c|c|c|}
\hline Pulun Yılı & Pulun Teması & Sayısı (n=5) \\
\hline 1980 & İslam Anma Serisi & 3 \\
\hline 1981 & İslam Ülkeleri Dayanışma Günü & 2 \\
\hline
\end{tabular}


Görsel 15. Din Temalı Pulların Bazıları (Soldan Sağa Pulların Yayınlanma Yılları 1980, 1981)

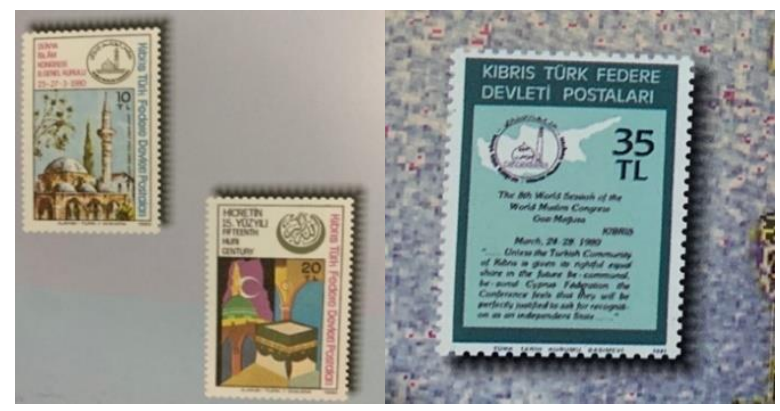

\section{SONUÇ VE DEĞERLENDİRME}

Posta pullarındaki sunum kodları ve temsiliyet konusu kültürel bellek açısından incelenen bu çalışmada 1970 ve 1998 yılları arasında Kuzey Kıbrıs özelinde sosyo-kültürel değişimleri ve Kıbrıs Türklerinin dünyaya uyum sağlama adına öne çıkardıkları konu ve durumları açıkça ortaya koymuştur. Bu bağlamda siyasi temsiller olarak öne çıkması öngörülen pulların aksine söz konusu dönemde doğa, sağlık gibi temalardaki pulların yoğunluğu siyasi propaganda amacından ziyade tanıtım amacı taşıdığını söylemek yanlış olmayacaktır. Çalışma kapsamında incelenen posta pullarında, tarihi mekanlar, çiçekler, hayvanlar ve resmi kurum ve kuruluşların kuruluşu anısına yapılan pullar dikkat çekmektedir. Bu açıdan, 1970-1998 yılları arasındaki pullar için Kuzey Kıbrıs Türk Cumhuriyeti’nin kuruluşu ve akabinde tanıtımı açısından önemli referans kaynaklar olduğunu söylemek yerinde olacaktır.

Posta pullarındaki sunum kodları içerisinde Türkiye Cumhuriyeti ile ilişkiler resmi devlet ziyaretleri için hazırlanan pullar ile metaforik olarak 1974’ü resmederken, dünya ile entegre olma isteği açısından spor teması altındaki Dünya Kupası ve Olimpiyatlar için hazırlanan pullar öne çıkmaktadır. Bunun yanı sıra Birleşmiş Milletler ve İngiliz Kraliyet ailesi ile ilgili çıkan pullarda ise adanın üzerindeki dış aktörlerin etkisi ve devamlılığı sunulmaktadır. Bunların yanında Kuzey Kıbrıs Türk Cumhuriyeti'nin kuruluşu ve önemli kişilerin yer aldığg pullarda ise temsil edilmek üzere seçilen kişiler Kuzey Kıbrıs Türk halkı için öne çıkan kişilerdir.

Kuzey Kıbrıs Türk Cumhuriyeti pullarını daha Cumhuriyet dönemi kurulmadan önceki dönemden başlayarak politik olarak 16 kategoriden oluşan ölçekle incelediğimiz bu çalışmada pulların ikonografik değerinin araştırma materyali olarak devletin, ulusun ve toplumun kültürel belleği bağlamında görsel temsilleri ortaya koyulmuştur. Her durumda söz konusu döneme ait pullar topluma ait kültürün sadece varlığını değil yokluğunu da gösteren birer anlatı olarak karşımıza çıkmaktadır. Öyle ki posta pullarındaki görsel temsiller bir topluma ve onun baskın değer yapılarına sembol oluştururken ulusal kimliğin inşasını da kronolojik olarak tarihin temsilleri şeklinde gözler önüne sermektedir.

Diğer batı toplumlarına nazaran bu çalışmadaki posta pullarında propagandacı ideolojilerden ve siyasal mesajların oranından çok toplumun oluşumundaki süreçler ön plana çıkmıştır. Bu nedenle, gelecek için siyasi mesajlar içeren propagandist tasarımlar yerine geçmişin yeniden üretimini öne çıkaran ve yıldönümleri, anmalarla birlikte unutulmamasını amaç edinen pullar daha fazladır. $\mathrm{Bu}$ çalışma belli bir dönemi ele alması açısından ve Kıbrıs özelinde yapılan pullarla ilgili ilk çalışma olması 
bakımından önemlidir. Fakat nitel bir araştırma olması ve ilk olması sebebiyle pullarla ilgili belgelerin haritası niteliğinde olan bu çalışma belirli bir dönemi işaret ettiği için sınırlıdır. İşaret ettiği dönemden sonraki dönemlerde haberleşme aracı olarak postanın önemini kaybetmesi düşünüldüğünde çalışma önemli veriler ortaya koymaktadır. Bu veriler ışığında gelecek çalışmalarda söz konusu dönemde pulları aktif olarak kullanan vatandaşlara yönelik pulların öğretim malzemesi olarak kullanılması üzerinden yeni çalışmalar yapılabileceği gibi söz konusu pulların görsel betimlemelerini de yapmak anlamlı olacaktır. Pullar bir ülkenin tarihini anlamamıza yardımcı olan görselleştirmelerdir ve bu açıdan karşılaştırmalı kapsamlı çalışmalar da ortaya değerli veriler koyacaktır.

\section{KAYNAKÇA}

Assmann, A. (2006). Memory, individual and collective. The Oxford handbook of contextual political analysis, 9, 210-226.

Banks, M. (2001). Visual Methods in Social Research. Sage, London.

Brunn S.D. and Yanarella E., (1987). Towards a humanistic political geography. Studies in Comparative International Development 22:(2) 349.

Brunn S.D. and Jones J.A., (1994). Geopolitical information and communication in shrinking and expanding worlds. In: Demko G.J. and Wood W.B. (eds), Reordering the World: Geopolitical Perspectives on the 21st Century. pp. 301-322. Westview Press, Boulder.

Brunn S.D., Baker J. and Cottle C., (1996). Small states' worldviews and 'windows' on the world: UN 50th anniversary speeches and 'official' WWW home pages. Paper presented at Eighth International Conference on the Advancement of Socio-Economics, University of Geneva, July.

Brunn, S.D. (2000).'Stamps as iconography: Celebrating the independence of new European and Central Asian states', GeoJournal, 52: 315-323.

Child, J. (2005). The politics and semiotics of the smallest icons of popular culture: Latin American postage stamps. Latin American Research Review, 108-137.

Conway, M. A., \& Pleydell-Pearce, C. W. (2000). The construction of autobiographical memories in the self-memory system. Psychological review, 107(2), 261.

Davis, B. (1985). "Maps on Postage Stamps as Propaganda". The Cartographic Journal, 22(2), s.125-130.

Deans, P., and Dobson H. (2005). "Introduction: East Asian Postage Stampsas Socio-Political Artefacts". East Asia, 22(2), 3-7.

Dobson, H. (2002). Japanese Postage Stamps: Propaganda and Decision Making. In Japan Forum (Vol. 14, No. 1, pp. 21-39). Taylor \& Francis. 
Goin, P. (2001). 'Visual literacy', in DELYSER, D. and STARRS, P.F. (eds): Doing Fieldwork, Geographical Review, 91 (Special Issue): 363-369.

Halbwachs, M. (1992). On collective memory. University of Chicago Press.

Hoelscher, S., \& Alderman, D. H. (2004). Memory and place: geographies of a critical relationship. Social \& Cultural Geography, 5(3), 347-355.

Klamár, R., Slivková, S., Javor, M., \& Brunn, S. D. (2018). Stamps of Czechoslovakia (19831992) and Slovak and Czech Republics (1993-2002): juxtaposing fragmentation and integration theory. Geografiska Annaler: Series B, Human Geography, 100(4), 377395.

Lauritzen, F. (1988). 'Propaganda art in the postage stamps of the Third Reich', Journal of Decorative and Propaganda Arts, 10: 62-79.

Lutz, C. and Collins, J.L. (1993). Reading National Geographic. University of Chicago Press, Chicago.

Matsuda, M. K., \& Matsuda, M. K. (1996). The memory of the modern. Oxford University Press on Demand.

Nuessel, F. and Cicogna, C. (1992). 'Postage stamps as pedagogical instruments in the Italian curriculum', Italica, 69: 210-227.

Olick, J. K., \& Robbins, J. (1998). Social memory studies: From "collective memory" to the historical sociology of mnemonic practices. Annual Review of sociology, 24(1), 105140.

Pierce, P. R., \& Zilka, A. M. (1996). U.S. Patent No. 5,584,017. Washington, DC: U.S. Patent and Trademark Office.

Raento, P. (2004). 'Where East meets West: International references on Finnish postage stamps, 1917-2001'. Paper presented at the international workshop 'Apolitical? East Asian Postage Stamps as Socio-Political Artefacts,' University of Sheffield, UK, 13-14 August.

Raento, P., \& Brunn, S. D. (2005). Visualizing Finland: Postage stamps as political messengers. Geografiska Annaler: Series B, Human Geography, 87(2), 145-164.

Raento, P. (2006). Communicating geopolitics through postage stamps: the case of Finland. Geopolitics, 11(4), 601-629.

Raento, P. (2016). A Geopolitics of the Horse in Finland. Geopolitics, 21(4), 945-968. 
Reid, D.M. (1984). 'The symbolism of postage stamps: A source of historians', Journal of Contemporary History, 19: 223-249.

Reid, D. M. (1993). "The Postage Stamp: A Windowon Saddam Hussein's Iraq". Middle East Journal, 47(1), s.77-89.

Rose, G. (1996). 'Teaching visualized geographies: Towards a methodology for the interpretation of visual materials', Journal of Geography in Higher Education, 20: 281294.

Rose, G. (2001). Visual Methodologies. An Introduction to the Interpretation of Visual Materials. Sage, London.

Scott, D. (1995). European Stamp Design: A Semiotic Approach to Designing Messages. Academy Editions, London.

Scott, D. (2002). 'The semiotics of the lieu de mémoire: The postage stamp as a site of cultural memory', Semiotica, 142: 107-124.

Scott, D. (2004). 'The politics and semiotics of postage stamp design. Paper presented at the international workshop 'Apolitical? East Asian Postage Stamps as Socio-Political Artefacts,' University of Sheffield, UK, 13-14 August.

Steiner, L., \& Zelizer, B. (1995). Competing memories: Reading the past against the grain: The shape of memory studies.

Sturken, M. and Cartwright, L. (2001). Practices of Looking. Oxford University Press, Oxford.

Van Leeuwen, T., \& Jewitt, C. (Eds.). (2001). The handbook of visual analysis. Sage.

Wang, Z. (2008). National humiliation, history education, and the politics of historical memory: Patriotic education campaign in China. International Studies Quarterly, 52(4), 783-806.

Yates, A. J. (1966). Psychological deficit. Annual review of psychology, 17(1), 111-144.

Zonabend, F. (1984). The enduring memory: Time and history in a French village. Manchester University Press. 